\title{
EVALUATION OF A SUMMARY SCORE FOR DYSLIPIDEMIA, OXIDATIVE STRESS AND INFLAMMATION (THE DOI SCORE) IN WOMEN WITH POLYCYSTIC OVARY SYNDROME AND ITS RELATIONSHIP WITH OBESITY
}

\author{
PROCENA ZBIRNOG SKORA DISLIPIDEMIJE, OKSIDATIVNOG STRESA I INFLAMACIJE \\ (DOI SKOR) KOD ŽENA SA SINDROMOM POLICISTIČNIH JAJNIKA \\ I NJEGOVA POVEZANOST SA GOJAZNOŠĆU
}

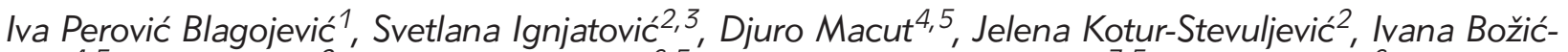 \\ Antić ${ }^{4,5}$, Jelena Vekić ${ }^{2}$, Jelica Bjekić-Macut ${ }^{6,5}$, Biljana Kastratović-Kotlica7,5, Zoran Andrić6, Dušan Ilić ${ }^{4}$ \\ ${ }^{1}$ Department of Laboratory Diagnostic, Clinical Hospital Center „Dr Dragiša Mišović - Dedinje«, Belgrade, Serbia \\ ${ }^{2}$ Department for Medical Biochemistry, Faculty of Pharmacy, University of Belgrade, Belgrade, Serbia \\ ${ }^{3}$ Center for Medical Biochemistry, Clinical Center Serbia, Belgrade, Serbia \\ ${ }^{4}$ Clinic of Endocrinology, Diabetes and Diseases of Metabolism, Clinical Center Serbia, Belgrade, Serbia \\ ${ }^{5}$ Faculty of Medicine, University of Belgrade, Belgrade, Serbia \\ ${ }^{6}$ University Medical Center »Bežanijska kosa«, Belgrade, Serbia \\ ${ }^{7}$ Clinic of Obstetrics and Gynekology, Clinical Center Serbia, Belgrade, Serbia
}

\begin{abstract}
Summary
Background: Polycystic ovary syndrome (PCOS) is a cardiometabolic disorder whose features include dyslipidemia, increased oxidative stress (OS, oxy) and chronic inflammation. The aim of this study was to investigate the ability of a summary score for dyslipidemia, OS and inflammation (the DOI score) to discriminate PCOS patients from healthy individuals and to evaluate the effect of obesity on individual scores and the DOI score in patients.

Methods: Lipid status parameters, OS status parameters (advanced oxidation protein products; total oxidative status; prooxidant-antioxidant balance; malondialdehyde; total protein sulphydryl groups and paraoxonase 1 activity) and CRP were measured in 114 patients and 50 controls using standardised assays. The DOI score was calculated as the sum of dyslipidemia, oxy and inflammation scores, determined as Z-score values for every subject in relation to the controls.

Results: PCOS patients had significantly higher oxy-score compared to controls $(P<0.001)$. In addition, the DOI
\end{abstract}

\section{Kratak sadržaj}

Uvod: Sindrom policističnih jajnika (PCOS) je kardiometabolički poremećaj čije su karakteristike dislipidemija, povišen oksidativni stres (OS) i hronična inflamacija. Cilj ove studije je bio da se ispita sposobnost zbirnog skora dislipidemije, OS i inflamacije (DOI skor) da razlikuje pacijentkinje sa PCOS u poređenju sa zdravim osobama i da se proceni uticaj gojaznosti na pojedinačne skorove i DOI skor kod pacijentkinja.

Metode: Parametri lipidnog statusa, parametri oksidativnog stresa (uznapredovali produkti oksidacije proteina; ukupni oksidativni status; prooksidativno-antioksidativni balans; malondialdehid; ukupne sulfhidrilne grupe i aktivnost paraoksonaze 1) i CRP su određivani kod 114 pacijentkinja i 50 kontrolnih ispitanica primenom standardizovanih testova. DOI skor je izračunat kao zbir skora dislipidemije, oksidativnog skora i skora inflamacije, određen kao vrednosti Z-skora za svaki subjekt u odnosu na kontrole.

Rezultati: PCOS pacijentkinje su imale značajno više vrednosti oksidativnog skora u poređenju sa kontrolnom grupom

\footnotetext{
Address for correspondence:

Iva Perović Blagojević, Specialist in Medical Biochemistry

Department of Laboratory Diagnostics, Clinical Hospital Center "Dr Dragiša Mišović - Dedinje«, Heroja Milana Tepića 1,

11000 Belgrade, Serbia

Tel: +381641624092

e-mail: ivapb17@gmail.com
}

List of abbreviations: OS, oxidative stress; DOI, dyslipidemia, oxidative stress, inflammation; CG, control group 
score was significantly higher in $P C O S$ patients $(P<0.001)$ as the dyslipidemia $(P<0.05)$ and inflammatory scores $(P<0.001)$ were greater. According to ROC analysis, the oxy-score showed better diagnostic accuracy in discriminating PCOS patients compared to the DOI score (AUC>0.9, $P<0.01)$. Furthermore, obesity affected the risk scores in patients, especially the DOI score (significantly higher DOI scores in such patients, $\mathrm{P}<0.001$ ).

Conclusion: PCOS patients had greater dyslipidemia, chronic inflammation and OS compared to controls and could be segregated using all four scores. Our data suggest that weight gain could be the common factor responsible for induction and propagation of dyslipidemia, OS and inflammation in PCOS patients.

Keywords: Polycystic ovary syndrome, dyslipidemia, oxidative stress, inflammation, DOI score, obesity

\section{Introduction}

Polycystic ovary syndrome (PCOS) is the most common endocrine disorder in women of reproductive age (prevalence of $6 \%-8 \%$ ) and is characterised by reproductive and hyperandrogenic features (1). In addition to endocrine disturbance, PCOS is a metabolic disorder whose central features are obesity, insulin resistance, hyperinsulinemia (2), dyslipidemia, increased oxidative stress (3), chronic inflammation (4) and subclinical atherosclerosis with a real risk of future cardiovascular disease (2).

Dyslipidemia is the most common metabolic abnormality in PCOS, with a prevalence of up to $70 \%$ according to the National Cholesterol Education Programme guidelines (lipid levels that are borderline or elevated) (3). Dyslipidemia usually includes reduced high-density lipoprotein cholesterol (HDL-C) and elevated both low-density lipoprotein cholesterol (LDL-C) and triglycerides. This form of atherogenic dyslipidemia together with low-grade inflammation has been associated with insulin resistance (5). Small dense LDL particles are particularly atherogenic forms of lipoprotein which may be increased in hyperandrogenic and insulin resistant PCOS patients (6). Additionally, elevated levels of oxidised LDL (OxLDL), a reliable predictor for coronary artery disease (CAD), have been detected in PCOS patients indicating that altered lipid metabolism in PCOS is associated with oxidative stress (OS) (7).

OS is defined as an imbalance between excessive formation of reactive oxygen species (ROS) and reduced antioxidant defence capacity. It is characterised by irreversible damage of practically all cellular components leading to impaired cell function. The pathophysiological mechanism of PCOS remains vague, but numerous studies have found that PCOS is associated with OS (8). The potential sources of ROS in PCOS are adipose tissue, fatty acid oxidation,
$(P<0,001)$. Zatim, DOI skor je bio značajno viši kod pacijentkinja sa PCOS $(P<0,001)$ kao i skorovi dislipidemije $(P<0,05)$ i inflamacije $(P<0,001)$. Prema rezultatima $R O C$ analize, oksidativni skor je pokazao bolju dijagnostičku tačnost $u$ razlikovanju PCOS pacijentkinja u odnosu na zdrave osobe $u$ poređenju sa DOI skorom (AUC>0,9, $\mathrm{P}<0,01)$. Osim toga, gojaznost je imala uticaj na vrednosti skorova rizika, posebno na DOI skor (vrednosti DOI skora su bile značajno više kod tih pacijentkinja, $P<0,001)$.

Zaključak: Pacijentkinje sa PCOS su imale izraženiju dislipidemiju, hroničnu inflamaciju i oksidativni stres u poređenju sa kontrolnim ispitanicama i mogu se od njih razlikovati primenom sva četiri skora. Naši rezultati ukazuju da povećanje telesne težine može biti zajednički faktor odgovoran za nastanak i napredovanje dislipidemije, OS i inflamacije kod pacijentkinja sa PCOS.

Ključne reči: sindrom policističnih jajnika, dislipidemija, oksidativni stres, inflamacija, DOI skor, gojaznost

hyperglycemia, activity of different enzymes (NADPH oxidase, xanthine oxidase, an uncoupled state of endothelial nitric oxidase) and mitochondrial dysfunction (9). OS is involved in the pathogenesis of insulin resistance, hyperandogenemia and obesity which often, but not always, accompany PCOS (9). Several circulating markers are currently used to assess $O S$ in PCOS: Homocysteine, malondialdehyde (MDA), asymmetric dimethylarginine (ADMA), advanced oxidation protein products (AOPPs), superoxide dismutase (SOD), glutathione (GSH) and paraoxonase 1 (PON1) (10). As pronounced OS can arise from reduced antioxidative protection, it is necessary to standardize ie measure all the OS parameters in each individual.

Chronic low-grade inflammation in PCOS patients is often seen via increased $\mathrm{C}$-reactive protein (CRP), WBC and IL-18 (11). OS is implicated in the development of endothelial dysfunction in PCOS, regardless of obesity and metabolic disturbances (12). Hyperglycaemia, chronic inflammation and insulin resistance lead to excessive ROS formation which exceeds the capacity of cellular antioxidant defence systems (13). ROS, by activating pro-inflammatory signalling pathways in endothelial cells, initiates the development of atherosclerosis (9).

Within the complex mechanisms mentioned above the key PCOS risk factors are dyslipidemia, OS and inflammation. In order to assess their mutual effects in PCOS, we have calculated a summary score for dyslipidemia, OS and inflammation (the DOI score). The aim of this study was to investigate the ability of a summary DOI score, as a potent indicator of its interactive role in PCOS, to discriminate patients from healthy individuals. In addition, we evaluated the effect of obesity on the values of individual scores and the DOI score in PCOS patients. 


\section{Materials and Methods}

\section{Subjects}

The study included 114 PCOS patients (median age 25.5 years and body mass index, BMI 24.2 $\mathrm{kg} / \mathrm{m}^{2}$ ) and 50 healthy females (median age 28.0 years and BMI $22.1 \mathrm{~kg} / \mathrm{m}^{2}$ ). Samples from all participants were collected during a 24-month period (October 2015 - June 2017) at the Clinic of Endocrinology, Diabetes and Metabolic Diseases, Clinical Centre of Serbia, Belgrade. Patients included in the study were referred to endocrinologists because of menstrual irregularity or hirsutism. PCOS was defined on the basis of the revised Rotterdam Consensus Criteria (2003) (14) by meeting 2 of the following 3 criteria: Moderate oligo/amenorrhea (less than eight menstrual cycles in a year), presence of clinical hyperandrogenism (hirsutism) and/or biochemical hyperandrogenemia, and the existence of polycystic ovaries confirmed by transvaginal ultrasonography. Patients were analysed during the early follicular phase of the menstrual cycle, or at any time if they had severe oligomenorrhea or amenorrhea.

The control group (CG) consisted of healthy women (normal glucose metabolism, non-smokers and zero alcohol consumers) with no signs of hyperandrogenism. The presence of hyperprolactinemia, hypothyroidism, non-classic 21-hydroxylase deficiency, Cushing's disease and androgen-secreting tumours in the CG were excluded by laboratory tests. CG females had not taken oral contraceptives, glucocorticoids or antiandrogens in the previous three months. The study was approved by the Institute's Ethics Committee and conducted respecting the principles set out in the latest amendment to the Declaration of Helsinki (Edinburgh, 2000). Written informed consent was voluntary obtained from all subjects. The study protocol was evaluated and approved by Ethics Committee of the Faculty of Medicine and Faculty of Pharmacy, University of Belgrade.

\section{Methods}

BMI and systolic and diastolic arterial blood pressure (SBP and DBP) were determined in all study participants. BMI was calculated as the ratio of body weight and body height squared. SBP and DBP were measured using a mercury sphygmomanometer on the left arm in a sitting position. The average of two measurements was calculated and used for analysis.

Blood samples were collected in the morning after a $12 \mathrm{~h}$ fasting period in the follicular phase of the cycle (on the 2 nd or the 3rd day) from both the PCOS patients and the CG or randomly in the case of severe oligomenorrhoea or amenorrhea (in PCOS patients). Plasma and serum were separated and stored at $-80{ }^{\circ} \mathrm{C}$ until analyses took place.
Total cholesterol (TC), HDL-C, triglyceride (TG) and CRP concentration were determined using commercially available enzymatic and turbidimetric tests on an automated biochemical analyser Dimension RxL Max (Siemens Healthcare GmbH, Germany). The concentration of LDL-C was calculated by the Friedewald formula (15). NonHDL-C (total cholesterol minus HDL-C) and the TG-to-HDL-C ratio (TG/HDL-C) were also determined in all study participants.

Advanced oxidation protein products (AOPP) were determined according to the Witko-Sarsat method using a reaction with glacial acetic acid and potassium iodide (16). Total oxidative status (TOS) was measured by a spectrophotometric method using o-dianisidine optimized by Erel (17). Total antioxidative status (TAS) was measured by a spectrophotometric method using ABTS as a chromogen (18). The method for prooxidant-antioxidant balance (PAB) used 3, 3', 5, 5'-tetramethylbenzidine as a chromogen (19). Malondialdehyde (MDA) was measured by spectrophotometry using the thiobarbituric acid-reactive substances (TBARS) assay (20). Total protein sulphydryl (SH-) groups were determined using a spectrophotometric method with 5,5'-dithiobis (2nitrobenzoic acid) (DTNB) (21). Superoxide dismutase (SOD) activity was measured according to a method which depended on the ability of the enzyme to inhibit autooxidation of epinephrine in alkaline medium (22). PON1 activity was measured kinetically using paraoxon (Chem Service, PA, USA) as the substrate by the method described by Richter and Furlong (23). All assays were performed on a llab 300+ (Instrumentation Laboratory, Milan, Italy).

As we wished to examine the mutual effect of the most important risk factors in PCOS patients, we calculated the DOI score as a sum of dyslipidemia, OS and inflammatory scores. To calculate the dyslipidemia score we standardised all the variables by calculating $Z$ scores for LDL-C, TG and HDL-C using mean and standard deviation calculated from the CG. Thereafter, the dyslipidemia score was calculated according to the equation: Average of the standardised variables (LDL-C+TG)/2 minus standardised HDL-C. The OS score (oxy-score) was calculated by subtracting the protective score from the damage score using the equation given by Veglia et al. (24). The protective score was calculated as an average of standardised antioxidant variables (total $\mathrm{SH}$-groups, TAS, SOD and PON1 activity) while the damage score was calculated as an average of standardised prooxidant factors (AOPP, TOS, PAB and MDA). The inflammation score was determined in both groups after standardisation of CRP as an acute phase protein. All variables with non-normal distributions were log-transformed before computation. 


\section{Statistical analysis}

Statistical analysis was performed using the Statistical Package for the Social Sciences (version18.0 for Windows, SPSS Inc., Chicago, IL, USA). Since the variables did not show normal Gaussian distributions the data are shown as median and interquartile range and comparisons between groups were made using the Mann-Whitney U or Kruskal-Wallis tests. Spearman's correlation analysis was used to evaluate the strength of association between the scores and multiple linear regression analysis was implemented to determine the mutual influence of obesity, lipid and OS parameters in PCOS patients. Areas under receiver operating characteristic curves (AUC-ROC) for the dyslipidemia, oxy, inflammation and summary DOI scores were calculated and the discriminative abilities of the models were classified according to their AUC values as poor $(0.5 \leq \mathrm{AUC}<0.7)$, acceptable $(0.7 \leq$ $A \cup C<0.8)$, excellent $(0.8 \leq A \cup C<0.9)$ or outstanding ( $A \cup C \geq 0.9$ ). A $P$ value $<0.05$ was considered statistically significant.

\section{Results}

The characteristics of the PCOS patients and CG subjects are presented in Table $I$.

The results are shown as the median values and interquartile range. After Mann-Whitney analysis, the following results were observed. HDL-C was significantly lower in PCOS patients compared to the CG. TC, nonHDL-C, LDL-C and TG did not significantly differ between the two groups. The atherogenic index (TG/HDL-C ratio) did not significantly differ between the two groups (even though the median value of the
TG/HDL ratio was higher in PCOS patients). PCOS patients had significantly higher CRP compared to the CG.

OS parameters in PCOS patients and the CG are presented in Figure 1.

Significantly higher prooxidant parameters (AOPP, TOS, PAB and MDA) were found in PCOS patients compared to the CG. PCOS patients had lower PON1 activity $(\mathrm{P}<0.05)$ and reduced concentration of $\mathrm{SH}$-groups $(\mathrm{P}<0.001)$, parameters of antioxidant protection, compared to the CG.

In order to assess the influence and extent of OS, dyslipidemia and inflammation in PCOS we calculated the oxy-score, a comprehensive index of OS status, dyslipidemia and inflammation scores as well as a summary DOI score (Figure 2).

As expected PCOS patients had a significantly higher oxy-score compared to the CG (the damage score was higher in PCOS patients and the protective score was lower in PCOS patients). The DOI score were higher in PCOS patients as the values of the dyslipidemia and inflammatory scores were higher than those in the CG.

Interrelationships between the different scores were assessed using Spearman's correlation analysis and are shown in Table II.

The oxy-score showed the strongest and most significant positive correlation with the dyslipidemia score $(\rho<0.001)$ and significant positive correlation with the inflammation score $(\rho<0.01)$. In addition, strong positive association was observed between the dyslipidemia and the inflammation scores $(\rho<0.001)$.

Table I Basic socio-demographic, clinical and biochemical data from the PCOS patients and the CG.

\begin{tabular}{|l|c|c|c|}
\hline Parameter & PCOS $(n=114)$ & Control group $(C G)(n=50)$ & $P$ \\
\hline BMl, kg/m ${ }^{2}$ & $24.2(21.2-29.7)$ & $22.1(20.7-23.5)$ & $<0.01$ \\
\hline Age, years & $25.5(22.0-29.2)$ & $28.0(23.7-30.0)$ & $<.177$ \\
\hline SBP, $\mathrm{mmHg}$ & $120(110-125)$ & $110(103-120)$ & 0.371 \\
\hline DBP, $\mathrm{mmHg}$ & $75.0(70.0-80.0)$ & $74.5(65.7-80.0)$ & 0.232 \\
\hline TC, mmol/L & $4.76(4.14-5.31)$ & $4.98(4.38-5.50)$ & $<0.01$ \\
\hline HDL-C, mmol/L & $1.40(1.10-1.80)$ & $1.60(1.32-1.95)$ & 0.653 \\
\hline nonHDL-C, mmol/L & $3.24(2.57-3.93)$ & $3.39(2.87-3.76)$ & 0.789 \\
\hline LDL-C, mmol/L & $2.84(2.19-3.28)$ & $2.81(2.53-3.12)$ & 0.745 \\
\hline TG, mmol/L & $0.840(0.657-1.42)$ & $0.930(0.712-1.37)$ & 0.173 \\
\hline TG/HDL-C & $0.644(0.387-1.20)$ & $0.503(0.401-0.876)$ & $<0.001$ \\
\hline CRP, mg/L & $1.90(0.70-3.70)$ & $0.55(0.40-1.00)$ & \\
\hline
\end{tabular}

$\mathrm{P}<0.05 ;<0.01 ;<0.001$

Data are presented as median and interquartile range

Continuous variables were compared using the Mann-Whitney $U$ test 

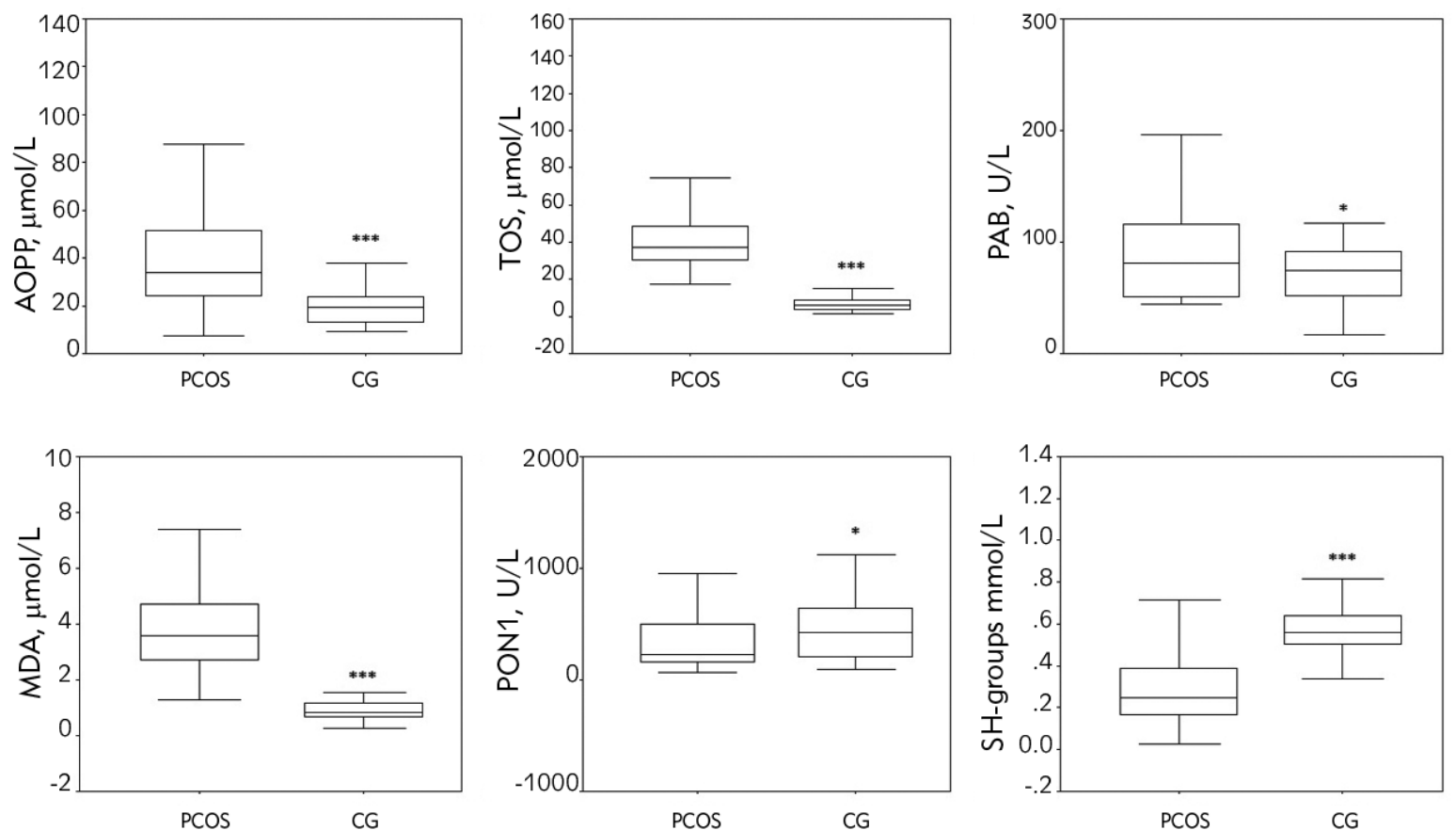

Figure 1 OS parameters in PCOS patients and the CG.

${ }^{*} * \mathrm{P}<0.001,{ }^{*} \mathrm{P}<0.05$ compared to $\mathrm{PCOS}$ patients, according to the Mann-Whitney $U$ test
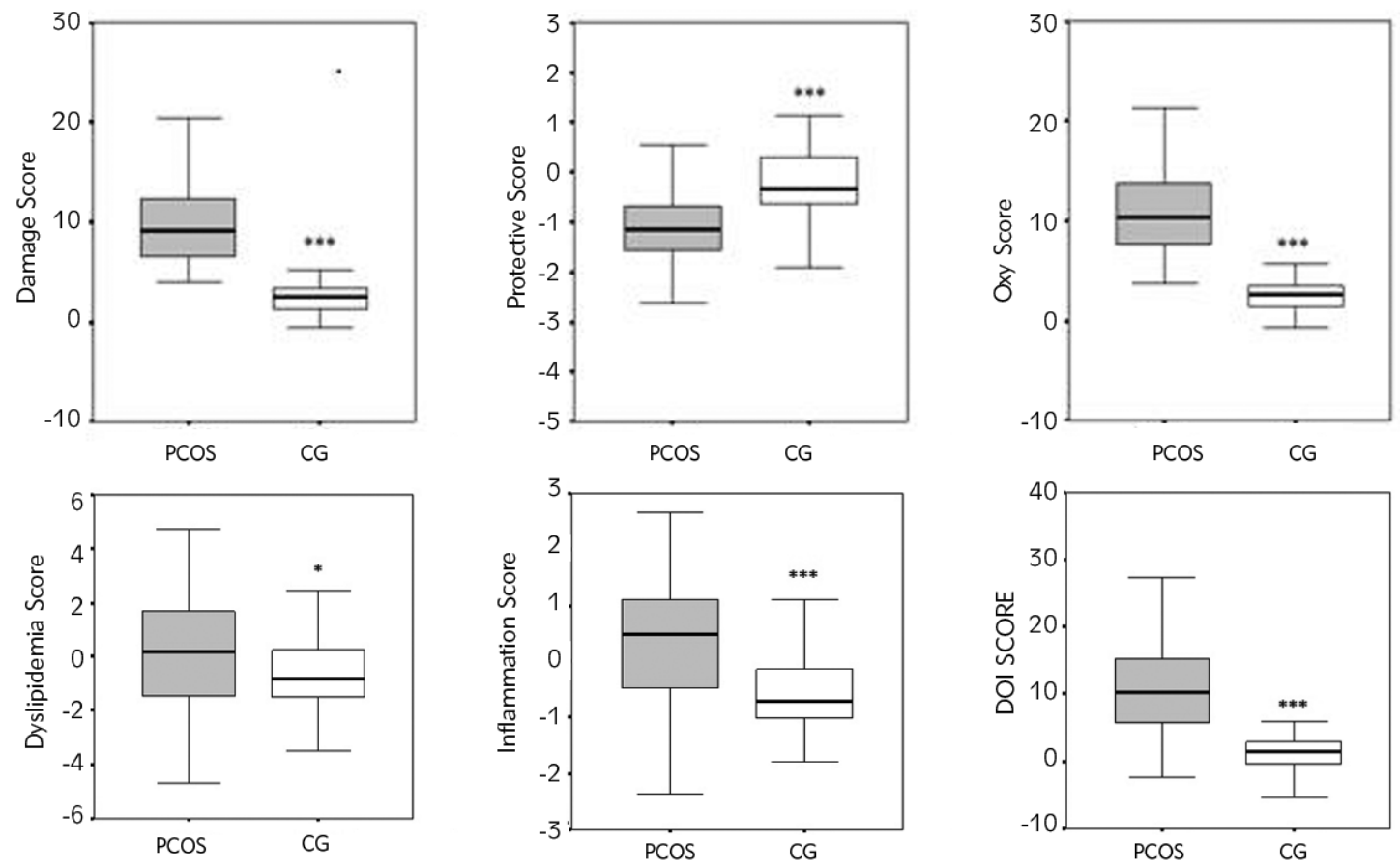

Figure 2 Risk scores (dyslipidemia, inflammation and oxy scores) in PCOS patients and the CG.

$* * * \mathrm{P}<0.001,{ }^{*} \mathrm{P}<0.05$ compared to the PCOS patients 
Table II Spearman's nonparametric correlation of risk scores in PCOS patients.

\begin{tabular}{|l|c|c|}
\hline Scores & $\begin{array}{c}\text { Dyslipidemia } \\
\text { score }\end{array}$ & $\begin{array}{c}\text { Inflammation } \\
\text { score }\end{array}$ \\
\hline Oxy-score & $0.397^{* * *}$ & $0.252^{* *}$ \\
\hline $\begin{array}{l}\text { Dyslipidemia } \\
\text { score }\end{array}$ & & $0.365^{* * *}$ \\
\hline
\end{tabular}

$\rho$-Spearman's correlation coefficient: ${ }^{* *} \rho<0.01$, $* * * \rho<0.001$

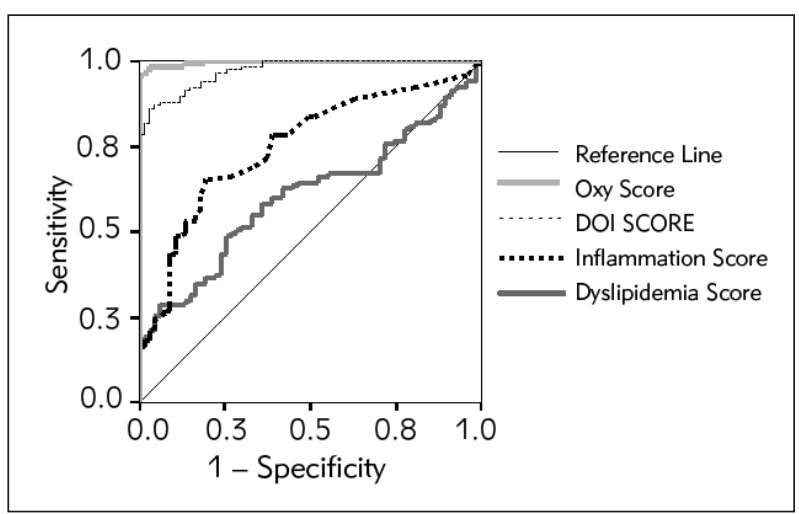

Figure 3 ROC curves for calculated scores as markers of PCOS.

Table III MLR analysis for predictors of oxy, inflammation and dyslipidemia score.

\begin{tabular}{|c|c|c|c|c|c|c|}
\hline & \multicolumn{2}{|c|}{ Oxy-score } & \multicolumn{2}{|c|}{ Inflammation score } & \multicolumn{2}{|c|}{ Dyslipidemia score } \\
\hline & $B(S E)$ & $95^{\text {th }} \mathrm{Cl}$ & $B(S E)$ & $95^{\text {th }} \mathrm{Cl}$ & $B(S E)$ & $95^{\text {th }} \mathrm{Cl}$ \\
\hline $\mathrm{BMI}$ & \multicolumn{2}{|r|}{ / } & $0.080(0.013)$ & $(0.055-0.105)^{\star * *}$ & $0.144(0.022)$ & $(0.100-0.188)^{\star * *}$ \\
\hline TC & $1.843(0.394)$ & $(1.062-2.623)^{* * *}$ & \multicolumn{2}{|r|}{ / } & \multicolumn{2}{|r|}{ / } \\
\hline HDL-C & $-2.911(0.806)$ & $(-4.509--1.313)^{* * *}$ & \multicolumn{2}{|r|}{1} & \multicolumn{2}{|r|}{ I } \\
\hline AOPP & \multicolumn{2}{|r|}{ I } & \multicolumn{2}{|r|}{ l } & 0.049 (0.007) & $(0.035-0.062)^{\star * *}$ \\
\hline TOS & \multicolumn{2}{|r|}{ / } & \multicolumn{2}{|r|}{ / } & $-0.018(0.007)$ & $(-0.032--0.005)^{\star *}$ \\
\hline MDA & \multicolumn{2}{|r|}{ / } & $0.123(0.057)$ & $(0.009-0.236)^{*}$ & $0.271(0.108)$ & $(0.0058-0.4840)^{*}$ \\
\hline Adjusted $R^{2}$ & \multicolumn{2}{|r|}{0.228} & \multicolumn{2}{|c|}{0.270} & \multicolumn{2}{|c|}{0.539} \\
\hline
\end{tabular}

Unstandardized beta coefficient (SE-Standard error); 95th $\mathrm{Cl}$; ${ }^{*} \mathrm{P}<0.05, * * \mathrm{P}<0.01,{ }^{* *} \mathrm{P}<0.001$ according MLR analysis

Table IV AUC for calculated scores after constructing ROC curves.

\begin{tabular}{|l|c|c|c|}
\hline Variable(s) & AUC (SE) & 95 th Cl & $P$ \\
\hline Oxy-score & $0.996(0.002)$ & $0.992-1.001$ & $<0.001$ \\
\hline DOI score & $0.972(0.009)^{\dagger \dagger}$ & $0.953-0.990$ & $<0.001$ \\
\hline $\begin{array}{l}\text { Inflammation } \\
\text { score }\end{array}$ & $0.751(0.037)^{\dagger \dagger \dagger, \ddagger \ddagger \ddagger}$ & $0.679-0.823$ & $<0.001$ \\
\hline $\begin{array}{l}\text { Dyslipidemia } \\
\text { score }\end{array}$ & $0.603(0.041)^{\dagger \dagger \dagger, \ddagger \ddagger \ddagger}$ & $0.522-.685$ & $<0.05$ \\
\hline
\end{tabular}

AUC - Area Under the Curve, P from ROC analysis - significance of the specific curve

$\uparrow, \uparrow \uparrow,+\uparrow \dagger$ - Significantly different from Oxy-score; $\ddagger, \ddagger \neq, \ddagger \ddagger \ddagger \ldots$ Significantly different from DOI score; $\mathrm{P}<0.05,0.01,0.001$
Multiple linear regression analysis (MLR) backward selection, was implemented to determine the mutual influence of obesity, lipid and OS parameters in PCOS patients. The best models which determined variability in the distinct scores are shown in Table III.

The main oxy-score predictors in PCOS patients were TC (positive correlation) and HDL-C (negative correlation). The adjusted $\mathrm{R}^{2}$ was 0.228 which indicated that approximately $23 \%$ of variability in oxyscore values was related to the selected parameters model. The most important predictors of the inflammation score were BMI and MDA (both with positive correlation, with $27 \%$ of variation). The dyslipidemia score was defined by BMI, AOPP, MDA (positive correlations) and TOS (negative correlation). This model explained $54 \%$ of influence on score variability. 
Table V Risk scores in obesity-related sub-groups of PCOS patients.

\begin{tabular}{|l|c|c|c|c|}
\hline Parameter & $\begin{array}{c}\text { PCOS, BMI }<25.0 \mathrm{~kg} / \mathrm{m}^{2} \\
(\mathrm{n}=55)\end{array}$ & $\begin{array}{c}\mathrm{PCOS}, \mathrm{BMI}=25.1-30.0 \mathrm{~kg} / \mathrm{m}^{2} \\
(\mathrm{n}=24)\end{array}$ & $\begin{array}{c}\text { PCOS, BMI }>30.0 \mathrm{~kg} / \mathrm{m}^{2} \\
(\mathrm{n}=35)\end{array}$ & $\mathrm{P}$ \\
\hline Dyslipidemia score & $-1.29(-2.34--0.09)$ & $1.13(0.19-2.71)^{\dagger \dagger \dagger}$ & $1.74(0.39-2.81)^{\dagger \dagger \dagger}$ & $<0.001$ \\
\hline Inflammation score & $-0.23(-0.80-0.93)$ & $0.79(-0.04-1.13) \dagger$ & $1.25(0.75-1.67)^{\dagger \dagger, \ddagger}$ & $<0.001$ \\
\hline Oxy-score & $9.37(7.17-13.40)$ & $12.31(9.88-15.91)^{\dagger \dagger}$ & $10.88(7.79-14.17)$ & $<0.001$ \\
\hline DOI score & $7.92(5.05-12.48)$ & $14.30(11.54-19.7)^{\dagger \dagger \dagger}$ & $14.56(9.31-18.01)^{\dagger \dagger}$ & $<0.001$ \\
\hline
\end{tabular}

$\dagger, \uparrow \uparrow, \uparrow \dagger \dagger$ - Significantly different from the first group (PCOS normal weight group)

$\ddagger, \ddagger \ddagger, \neq \ddagger$ - Significantly different from the second group (PCOS overweight group) $\mathrm{P}<0.05,0.01,0.001$

In order to evaluate the ability of all the scores to identify PCOS patients, we performed ROC curve analysis (Figure 3) and compared the scores using their AUC values (Table IV).

Both, oxy and DOI scores had larger AUCs (AUC > 0.9) compared to the inflammation and dyslipidemia scores meaning that these two scores exhibited outstanding discriminitive abilities. This is supported by the high sensitivity (97\%) and specificity (97\%) of the oxy-score and also the sensitivity (88\%) and specificity $(88 \%)$ for the DOI score at the cut-off value. Interestingly, the oxy-score showed better diagnostic accuracy in discriminating PCOS patients $(P<0.01)$ compared to the DOI score.

As multiple regression analysis indicated that BMI was an important predictor for both inflammatory and dyslipidemia scores, we examined how obesity affected all the risk scores in PCOS patients. We divided the PCOS patients into three subgroups according to $B M I$ values. The first subgroup consisted of normal weight patients $\left(B M l<25 \mathrm{~kg} / \mathrm{m}^{2}\right)$, the second group consisted of overweight patients $(B M I=25.1-30.0$ $\mathrm{kg} / \mathrm{m}^{2}$ ) and the third group consisted of obese patients $\left(\mathrm{BMI}>30.0 \mathrm{~kg} / \mathrm{m}^{2}\right)$ (Table V).

Normal weight PCOS patients had significantly lower dyslipidemia and inflammation scores compared to both overweight and obese patients. The calculated DOI score in normal weight PCOS patients compared to both overweight and obese patients was also significantly lower, while their oxy-score level did not differ from obese patients, but it was significantly lower compared to overweight PCOS patients. When risk scores between overweight and obese PCOS patients were examined only the inflammation score differed (significantly higher in obese PCOS patients).

\section{Discussion}

It was shown that PCOS clinical characteristics: dyslipidemia, increased OS and chronic inflammation can promote dysregulation of the ovarian thecal compartment and endothelial dysfunction resulting in hyperandrogenism, anovulation and early atherosclerosis (3). In the current study, by using specific biochemical indices, we have examined the ability of a summary score for dyslipidemia, OS and inflammation (the DOI score) to discriminate PCOS patients, prone to develop cardiometabolic consequences, from healthy females.

Dyslipidemia is the most common metabolic abnormality in PCOS patients, although the extent and type of dyslipidemia is variable (3). Dyslipidemia is characterised by significantly lower HDL, a lipoprotein that is thought to be the strongest metabolic predictor of coronary heart disease (25) and hypertriglyceridemia which has been found in both younger and older age groups $(5,26)$. However, some investigators have not found differences in circulating lipid levels in women with PCOS when compared with BMI-matched controls (27). In our study, we found decreased HDL-C concentration in PCOS patients compared to the $C G$, without any significant difference in TG, nonHDL-C and the atherogenic index (Table I). Furthermore, TC and LDL-C were not increased in PCOS patients (Table I). There is wide variability of data in studies regarding LDL-C in PCOS patients. Several studies have reported increased LDL-C and alterations in LDL quality in PCOS patients. LDL consists of different subclasses according to size, density and atherogenicity. Small dense LDL particles are more atherogenic then large buoyant ones and there is continuous increase in the LDL atherogenicity with decreasing particle size in PCOS patients $(3,28)$. However, all of the above-mentioned studies included primarily overweight or obese PCOS patients. A Korean study (29) revealed that there were no significant quantitative or qualitative changes in the LDL profile of non-obese PCOS patients. A large meta study (30) indicated that LDL-C was significantly elevated in PCOS patients, but also that LDL-C was influenced by many variables, including ethnicity, severity of syndrome (anovulatory vs. ovula- 
tory forms), quality of food and BMI. However, after calculating the dyslipidemia score, we found a significantly higher score in PCOS patients compared to the CG although only HDL-C was significantly lower in PCOS patients, while other lipid parameters did not differ between the examined groups (Figure 2). HDL particles prevent $L D L$ particle oxidation and have antiatherogenic and anti-inflammatory properties. It has been suggested that PCOS patients not only have decreased HDL-C but also altered HDL quality (31). Decreased $\mathrm{HDL}_{2}$ subfraction (the most anti-atherogenic HDL subtype) has been observed in PCOS patients (25). We can assume that decreased HDL-C and changed composition of HDL-C particles represents the initial step in the development of dyslipidemia in PCOS patients. Moreover, it could also be associated with propagation of OS and inflammation, as a consequence of the reduced anti-oxidative and anti-inflammatory capacity of low HDL-C.

Inflammation is clearly involved in the initiation and progression of atherosclerosis and there is a close relationship between chronic inflammation and OS in the atherosclerotic pathological process (32). Obesity affects cardiovascular risk in PCOS patients because it promotes chronic low-grade inflammation causing an increase in inflammatory markers (CRP, TNF- and IL6) (33). There is direct correlation between the levels of inflammatory markers in PCOS and patient BMI, as overweight and obese PCOS patients have significantly higher levels of these markers compared to weight-matched controls (34). Our results incorporating the inflammatory marker CRP, a powerful independent predictor of CVD, confirmed this. CRP levels were significantly higher in our PCOS patients compared to the CG, but the values were lower than 3.5 $\mathrm{mg} / \mathrm{L}$ which indicated low-grade inflammation. Regarding that, the inflammation score was significantly higher in PCOS patients compared to the CG.

OS has been recognised as an undesirable factor present in various pathological disorders including PCOS. Serum prooxidants and antioxidants are altered in PCOS patients, causing redox imbalance and promotion of OS. PCOS patients have increased OS markers such as MDA, the end-product of lipid peroxidation, reflecting oxidative-induced cell damage. AOPP, a marker of oxidant-mediated protein damage and a potent inflammatory mediator, total oxidant status (TOS), an aggregative index of plasma oxidant state and prooxidant-antioxidant balance $(P A B)$, a parameter reflecting concomitant existance of prooxidants and antioxidants in living systems have all been found to be elevated in PCOS patients $(10$, $35,36)$. Our current observations (Figure 1) concur with previous data. PCOS patients have diminished antioxidative protection parameters such as PON1 (an antioxidant enzyme) and total $\mathrm{SH}$-groups as scavengers of free radicals $(10,37)$. The first study reporting reduced serum PON1 activity in PCOS patients was a study by Dursun et al. (38). The authors sug- gested that decreased serum PON1 activity may have contributed to increased susceptibility towards the development of insulin resistance and atherosclerotic heart disease in PCOS patients. Another study (39) also showed that PCOS patients had reduced antioxidant PON1 activity and suggested that they were oxidatively stressed which may have been related to increased atherosclerosis seen later in life. Our PCOS patients had both decreased PON1 activity as well as $\mathrm{SH}$-groups compared to the CG (Figure 1). The exact mechanism behind decreased PON1 in PCOS patients is not known. Reduced PON1 can contribute to OS because PON1 is an antioxidative enzyme that prevents oxidation of lipoproteins by hydrolysing atherogenic products of oxidative lipid modification (10). In order to assess OS we used the oxy-score, a comprehensive index of OS derived from computation of different variables relevant for oxidative balance (24).

As several risk factors are intimately involved in complex PCOS pathology we combined three of them and calculated the DOI score (sum of dyslipidemia, oxy and inflammation scores). As expected, all scores were significantly increased in PCOS patients compared to the CG (Figure 2). Since the values of all three scores were increased in PCOS patients, the DOI score was significantly higher in PCOS patients, indicating the usefulness of this result for assessing cardiometabolic risk factors in PCOS patients.

A direct correlation between obesity and both insulin resistance and OS in PCOS patients has been demonstrated (40). OS participates in the pathogenesis of obesity mainly by inducing chronic inflammation and adipose tissue dysfunction (41). Furthermore, it appears that both adipose tissue dysfunction and obesity promote dyslipidemia, chronic inflammation and OS. The main predictors of the oxy-score in our PCOS patients were TC (positive correlation) and HDL-C (negative correlation). The most important predictors of the inflammation score in our PCOS patients were BMI and MDA (both with positive correlation), while independent factors of the dyslipidemia score in our PCOS patients were BMI, AOPP and MDA (positive correlation) and TOS (negative correlation) (Table III). AUC-ROC analysis revealed that both the oxy- and the summary DOI scores were outstanding cardiovascular risk indices for PCOS patient outcomes (Table IV).

The effect of obesity on markers of OS, inflammation and dyslipidemia in PCOS patients has been widely examined (42). In our study BMI was an independent predictor of both dyslipidemia and inflammation scores, as opposed to the oxy-score whose independent predictors were TC and HDL-C. Following on from this, overweight and obese PCOS patients had significantly higher dyslipidemia and inflammatory scores as well as the DOI score when compared to normal weight subjects (Table V). 
Adipose tissue is a dynamic endocrine organ that is involved in the secretion of different hormones and cytokines. Functional abnormalities of adipocytes are observed in PCOS patients. These abnormalities can promote mild inflammation and OS due to hypertrophy when exposed to androgen excess (9). These hypertrophic adipocytes have been identified as a source of proinflammatory cytokines that are potent stimulators of ROS and low-grade inflammation (3). Together our data suggest that weight gain could be the common factor responsible for induction and propagation of dyslipidemia, OS and inflammation in PCOS patients.

In conclusion, our results indicate that PCOS patients display more pronounced dyslipidemia, chronic inflammation and OS compared to the CG and can be segregated by the dyslipidemia, oxy and inflammation scores. The summary DOI score, as well as the oxy-score, show remarkable abilities to identify PCOS patients (AUC 0.9, which is outstanding diagnostic accuracy), compared to the inflammation and dyslipidemia scores.

\section{References}

1. Collinson P. Laboratory medicine is faced with the evolution of medical practice. J Med Biochem 2017; 36: 211-5.

2. Macut D, Bačević $M$, Božić-Antić I, Bjekić-Macut J, Čivčić $M$, Erceg $S$ et al. Predictors of subclinical cardiovascular disease in women with PCOS: interrelationship of dyslipidemia and arterial blood pressure. Int J Endocrinol 2015; 2015: 1-9.

3. Macut D, Bjekić-Macut J, Savić-Radojević A. Dyslipidemia and oxidative stress in PCOS. Front Horm Res 2013; 40: 51-63.

4. Repaci A, Gambineri A, Pasquali R. The role of lowgrade inflammation in the polycystic ovary syndrome. Molec Cell End 2011; 335: 30-41.

5. Macut D, Micić D, Cvijović G, Šumarac $M$, Kendereški $A$, Zorić $S$ et al. Cardiovascular risk in adolescent and young adult obese females with polycystic ovary syndrome (PCOS). J Pediatr Endocrinol Metab 2001; 14: 1353-9.

6. Dejager S, Pichard C, Giral P, Bruckert E, Federspield MC, Beucler I et al. Smaller LDL particle size in women with polycystic ovary syndrome compared to control. Clin Endocrinol 2001; 54: 455-62.

7. Perovic Bragojevic I, Eror T, Pelivanovic J, Jelic S, KoturStevuljevic J, Ignjatovic S. Women with polycystic ovary syndrome and risk of cardiovascular disease. J Med Biochem 2017; 36: 259-69.

8. Gonzalez F, Rote NS, Minium J, Kirwan JP. Reactive oxygen species-induced oxidative stress in the development of insulin resistance and hyperandrogenism in polycystic ovary syndrome. J Clin Endocrinol Metab 2006; 91: 336-40.

9. Papalou O, Victor VM, Diamanti-Kandarakis E. Oxidative
Our mode of assessment is relevant and applicable for cardiovascular risk prediction. In order to achieve further solid conclusions our study must be extended prospectively in order to monitor progression of dyslipidemia, inflammation and OS parameters via the DOI score and to assess the effect of therapy on reducing the overall cardiovascular risk in the PCOS patients later in their life.

Acknowledgements. This work was supported by Grants 41009, 175032 and 175035 from the Serbian Ministry of Science and Education. The study funder had no role in study design, in collection, analysis and interpretation of data; nor in the writing of the report and decision to submit the manuscript for publication.

\section{Conflict of interest statement}

The authors stated that they have no conflicts of interest regarding the publication of this article.

stress in polycystic ovary syndrome. Curr Pharm Des 2016; 22: 2709-22.

10. Murri $M$, Luque-Ramirez $M$, Insenser $M$, Ojeda-Ojeda $M$, Escobar-Morreale HF. Circulating markers of oxidative stress and polycystic ovary syndrome (PCOS): a systematic review and meta-analysis. Human Reproduction Update 2013; 19: 268-88.

11. Kaya C, Pabuccu R, Berker B, Satiroglu H. Plasma interleukin-18 levels are increased in the polycystic ovary syndrome: relationship of carotid intima-media wall thickness and cardiovascular risk factors. Fertil Steril 2010; 93: 1200-7.

12. Lambert EA, Teede $\mathrm{H}$, Sari $\mathrm{Cl}$, Jona E, Shorakae S, Woodington $\mathrm{K}$ et al. Sympathetic activation and endothelial dysfunction in polycystic ovary syndrome are not explained by either obesity or insulin resistance. Clin Endocrinol 2015; 83: 812-9.

13. Macut D, Simić T, Lissounov A, Plješa-Ercegovac $M$, Božić I, Djukić $T$ et al. Insulin resistance in non-obese women with polycystic ovary syndrome: relation to byproducts of oxidative stress. Exp Clin Endocrinol Diabetes 2011; 119: 451-5.

14. The Rotterdam ESHRE/ASRM-Sponsored PCOS Consensus Workshop Group. Revised 2003 consensus on diagnostic criteria and long-term health risks related to polycystic ovary syndrome (PCOS). Hum Reprod 2003; 19: 41-7.

15. Warnick GR, Knopp RH, Fitzpatrick V, Branson L. Estimating low-density lipoprotein cholesterol by the Friedewald equation is adequate for classifying patients on the basis of nationally recommended cutpoints. Clin Chem 1990; 36: 15-9. 
16. Witko-Sarsat $V$, Friedlander $M$, Capeillère-Blandin $C$, Nguyen-Khoa T, Nguyen AT, Zingraff J et al. Advanced oxidation protein products as a novel marker of oxidative stress in uremia. Kidney Int 1996, 49: 1304-13.

17. Erel O. A new automated colorimetric method for measuring total oxidant status. Clin Biochem 2005, 38: $1103-11$.

18. O. Erel, A novel automated direct measurement method for total antioxidant capacity using a new generation, more stable ABTS radical cation. Clin Biochem 2004; 37: 277-85.

19. Alamdari DH, Paletas K, Pegiou T, Sarigianni M, Befani C, Koliakos G. A novel assay for the evaluation of the prooxidant-antioxidant balance, before and after antioxidant vitamin administration in type II diabetes patients. Clin Biochem 2007, 40: 248-54.

20. Girotti MJ, Khan N, McLellan BA. Early measurement of systemic lipid peroxidation products in plasmaof major blunt trauma patients. J Trauma, 1991, 31: 32-5.

21. Ellman GI. Tissue silfhydryle groups. Arc Biochem Biophys, 1959, 82: 70-7.

22. Misra HP, Fridovich I. Chemistry and metabolism of substances of low molecular weight: the role of superoxide anion in the autoxidation of epinephrine and a simple assay for superoxide dismutase. J Biol Chem 1972; 247: 3170-5.

23. Kotur-Stevuljević J, Bogavac-Stanojević N, Jelić-Ivanović Z, Stefanović A, Gojković T, Joksić J et al. Oxidative stress and paraoxonase 1 status in acute ischemic stroke patients. Atherosclerosis 2015; 241: 192-8.

24. Veglia F, Cighetti G, De Franceschi M, Zingaro L, Boccotti $L$, Tremoli $E$ et al. Age- and gender-related oxidative status determined in healthy subjects by means of OXY-SCORE, a potential new comprehensive index. Biomarkers 2006; 11: 562-73.

25. Talbott E, Clerici A, Berga SL, Kuller L, Guzick D, Detre $\mathrm{K}$ et al. Adverse lipid and coronary heart disease risk profiles in young women with polycystic ovary syndrome: a result of a case-control study. J Clin Epidemiol 1998; 51: 415-22.

26. Glueck CJ, Morrison JA, Goldenberg N, Wang P. Coronary heart disease risk factors in adult premenopausal white women. Metabolism 2009; 58: 714-21.

27. Holte J, Bergh T, Berne C, Lithell H. Serum lipoprotein lipid profile in women with polycystic ovary syndrome: relation to anthropometric, endocrine and metabolic variables. Clin Endocrinol 1994; 41: 463-71.

28. Sidhwani S, Scoccia B, Sunghay S, Stephens-Archer CN, Mazzone T, Sam S. PCOS is associated with atherogenic changes in lipoprotein particle number and size independent of body weight. Clin Endocrinol 2011; 75: 76-82.

29. Kim JJ, Chae SJ, Choi YM, Hwang KR, Song SH, Yoon $\mathrm{SH}$ et al. Atherogenic changes in low-density lipoprotein particle profiles were not observed in non-obese women with polycystic ovary syndrome. Hum Reprod 2013; 28: 1354-60.
30. Wild RA, Rizzo M, Clifton S, Carmina E. Lipid levels in polycystic ovary syndrome: systematic review and metaanalisys. Fertil Steril 2011; 95: 1073-9.

31. Kim JJ, Choi YM. Dyslipidemia in women with polycystic ovary syndrome. Obstet Gynecol 2013; 56: 137-42.

32. Kotur-Stevuljević J, Memon L, Stefanović A, Spasić S, Spasojević-Kalimanovska V, Bogavac-Stanojević $\mathrm{N}$ et al. Correlation of oxidative stress parameters and inflammatory markers in coronary artery disease patients. Clin Biochem 2007; 40: 181-7.

33. Kaplan M, Ates I, Yüksel M, Ozderin Ozin Y, Yener Akpinar M, Topcuoglu C, Kayaçetin E. The role of oxidative stress in the etiopathogenesis of gluten-sensitive enteropathy disease. J Med Biochem 2017: 36: 243-50.

34. Escobar-Morreale HF, Luque-Ramírez M, González F. Circulating inflammatory markers in polycystic ovary syndrome: a systematic review and metaanalysis. Fertil Steril 2011; 95: 1048-58.

35. Kaya C, Erkan AF, Cengiz SD, Dunder I, Demirel OE, Bilgihan A. Advanced oxidation protein products are increased in women with polycystic ovary syndrome: relationship with traditional and nontraditional cardiovascular risk factors in patiens with polycystic ovary syndrome. Fertil Steril 2009; 92: 1372-7.

36. Heshmati N, Shahgheibi S, Nikkhoo B, Amini S, Abdi M. Association of prooxidant-antioxidant balance with clinical and laboratory parameters and its relation to different drug regimens in polycystic ovary syndrome women with normal BMI. Indian J Clin Biochem 2017; 32: 315-22.

37. Artimani T, Karimi J, Mehdizadeh M, Yavangi M, Khanlarzadeh $E$, Ghorbani $M$ et al. Evaluation of pro-oxidantantioxidant balance (PAB) and its association with inflammatory cytokines in polycystic ovary syndrome (PCOS). Gynecol Endocrinol 2017; 4: 1-5.

38. Dursun P, Demirtas E, Bayrak A, Yarali H. Decreased serum paraoxonase 1 (PON1) activity: an additional risk factor for atherosclerotic heart disease in patients with PCOS? Hum Reprod 2006; 21: 104-8.

39. Baskol G, Aygen E, Erdem F, Caniklioglu A, Narin F, Sahin $\mathrm{Y}$, Kaya T. Assessment of paraoxonase 1, xanthine oxidase and glutathione peroxidase activities, nitric oxide and thiol levels in women with polycystic ovary syndrome. Acta Obstetricia Gynecol Scandinavica 2012; 91: 326-30.

40. Chen L, Xu WM, Zhang D. Association of abdominal obesity, insulin resistance, and oxidative stress in adipose tissue in women with polycystic ovary syndrome. Fertil Steril 2014; 102: 1167-74.

41. Marseglia L, D Angelo G, Manti S, Aversa S, Arrigo T, Reiter RJ, Gitto E. Oxidative stress in obesity: a critical component in human disease. Int J Mol Sci 2015; 16: $378-400$.

42. Sam S. Obesity and Polycystic Ovary Syndrome. Obes Manag 2007; 3: 69-73. 